\title{
FLORAL BIOLOGY AND BEEKEEPING POTENTIAL OF Croton heliotropiifolius KUNTH (EUPHORBIACEAE) AT SEMI ARID REGION, BRAZIL
}

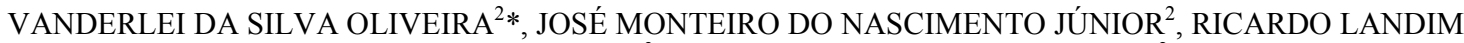 \\ BORMANN DE BORGES ${ }^{3}$, LUCIENE CRISTINA LIMA E LIMA ${ }^{2}$
}

\begin{abstract}
The aim of the present study was to determine the beekeeping potential of Croton heliotropiifolius Kunth (Euphorbiaceae) based on flowering strategy, floral characteristics, available floral resources, and the individuals frequencies and foraging activities of Apis mellifera L. on its flowers in Fazenda Ingazeira, Brazil. Each $C$. heliotropiifolius plant possessed inconspicuous diclinous flowers clustered into $560 \pm 60$ dense terminal inflorescences containing $59 \pm 12$ pistillate and $160 \pm 26$ staminate flowers. Although both types of flowers produced nectar (pistillate: $2.8 \pm 0.8 \mu \mathrm{L}$; staminate: $0.3 \pm 0.06 \mu \mathrm{L}$ ), A. mellifera workers mostly visited staminate flowers $(98 \%)$ during the peak visitation period (08:00-11:00 h). Moreover, during the foraging period, each plant produced approximately $5.376 \times 10^{8}$ pollen grains, ensuring approximately 33 visitation cycles from a colony of $A$. mellifera workers that picked up an average of 405 pollen grains per visit per flower. Further, $C$. heliotropiifolius showed an annual cornucopia flowering strategy with high flower production for five months, which is an important characteristic that ensures floral resource availability in the environment. These findings suggest that $C$. heliotropiifolius has a great potential for apiculture in this region.
\end{abstract}

Keywords: Apiculture. Apis mellifera L.. Caatinga. Floral resources.

\section{BIOLOGIA FLORAL E POTENCIAL APÍCOLA DE Croton heliotropiifolius KUNTH (EUPHORBIACEAE) NA REGIÃO DO SEMI-ÁRIDO, BRASIL}

\begin{abstract}
RESUMO - O presente estudo teve por objetivo determinar o potencial apícola de Croton heliotropiifolius Kunth, baseado na sua estratégia de floração, características florais, recursos florais ofertados, frequência e atividade de forrageamento de indivíduos de Apis mellifera L. às flores na Fazenda Ingazeira, Brasil. $C$. heliotropiifolius possui flores díclinas e inconspícuas agrupadas em densas inflorescências terminais, em que cada indivíduo produz $560 \pm 60$ inflorescências, com $59 \pm 12$ flores pistiladas e $160 \pm 26$ flores estaminadas, tendo cada flor estaminada a capacidade de produzir aproximadamente $6 \times 10^{3}$ grãos de pólen. Embora ambas as flores produzam néctar $(2,8 \pm 0,8$ e $0,3 \pm 0,06 \mu \mathrm{L}$, nas flores pistiladas e estaminadas, respectivamente), os espécimes de $A$. mellifera concentraram suas visitas nas flores estaminadas (98\%), com pico das visitações registrados entre 08:00-11:00 h. Foi estimado que nas atividades de forrageamentos, essa abelhas removem em média 405 grãos de pólen por visita em cada flor, desta forma, como um indivíduo da espécie estudada pode produzir aproximadamente $5,376 \times 10^{8}$ grãos de pólen, tal quantidade é suficiente para suportar até 33 ciclos de visitações de uma colônia de $A$. mellifera. Além disso, $C$. heliotropiifolius apresentou um padrão de floração anual, com altas produções de flores por cinco meses, manifestando estratégia de floração cornucópia, representando uma característica importante por favorecer na maior disponibilização de recursos florais nos ambientes. Portanto, esses dados demostram o grande potencial de C. heliotropiifolius para a apicultura na região.
\end{abstract}

Palavras-chave: Apicultura. Apis mellifera. Caatinga. Recursos florais.

\footnotetext{
${ }^{*}$ Corresponding author

${ }^{1}$ Received for publication in $09 / 02 / 2020$; accepted in $05 / 12 / 2021$.

Paper extracted from the master dissertation of the first author.

${ }^{2}$ Postgraduate Program in Plant Biodiversity, Universidade do Estado da Bahia, Paulo Afonso, BA, Brazil; vanderleivso2013@gmail.com ORCID: 0000-0002-6876-6286, juniormonteiro50@gmail.com - ORCID: 0000-0002-8778-6557, 1lima@gd.com.br - ORCID: 0000-00031541-2991.

${ }^{3}$ Laboratory of Palynological Studies, Department of Human Sciences, Universidade do Estado da Bahia, Caetité, BA, Brazil; rlborges@uneb.br-ORCID: 0000-0001-6636-3283.
} 


\section{INTRODUCTION}

Members of Euphorbiaceae, an angiosperm family with 300 genera and more than 8,000 species, occur in tropical regions that harbor different types of habitats and vegetation (GBIF SECRETERIAT, 2019). A total of 66 genera and 973 species of this family have been documented in Brazil, and approximately $24 \%$ of these species are found in the Caatinga phytogeographical domain (SILVA et al., 2020). Among the 66 genera, Croton is the most abundant, with more than 300 species identified from different vegetation domains in the northeastern region of Brazil, where they occur in dry to humid regions and even on rocky outcrops (SILVA et al., 2010; CARUZO et al., 2020).

The shrub species Croton heliotropiifolius Kunth, is widely distributed in the northeastern region and less frequently in the central-western and southeastern regions of Brazil (HURBATH; CARNEIRO-TORRES; ROQUE, 2016). Plants of this species are well-adapted to desert environments with high anthropization, forming dense populations (SILVA et al., 2010). The species is ecologically significant because it contributes to the reestablishment of the edaphic balance by supplying mineral nutrients and organic matter to the soil (GOREVITCH; SCHEINER; FOX, 2009; MORIMITSU; VERGENE; TOMAZ, 2014), as well as food resources for the fauna (BLUTHGEN, 2012).

Previous studies on floral biology have reported high frequencies of bees exploiting the floral resources of Croton species, primarily the Apis mellifera L. workers (REDDI; SUBBA-REDDI, 1985; PASSOS, 1995; PIRES; SOUSA; TERADA, 2004), and 19 Croton species have already been identified as important resources for apiculture in semi-arid regions (SANTOS et al., 2006). As most plants of apicultural importance are herbs or shrubs considered as weeds, they have been extensively subjected to deforestation (SANTOS et al., 2006). Thus, it is necessary to study their floral biology, with an emphasis on the bees that visit and exploit these resources, for the sustainable use of plant species and the diverse bee species that exploit their floral resources (ABOU-SHAARA, 2015).

Therefore, the aim of this study was to assess the potential of $C$. heliotropiifolius for apiculture in semi-arid regions. Furthermore, we determined the floral biology and floral resources (pollen grains and nectar) of this species, which are explored by $A$. mellifera individuals, to assess the ability of the plants to provide these resources.

\section{MATERIALS AND METHODS}

\section{Study site}

We investigated the flowering phenology and floral biology of $C$. heliotropiifolius in Fazenda Ingazeira $\left(13^{\circ} 54^{\prime} 48.1^{\prime \prime} \mathrm{S}, \quad 42^{\circ} 23^{\prime} 6.8^{\prime \prime} \mathrm{W}\right)$ in the municipality of Caetité, southwestern Bahia, Brazil. Fazenda Ingazeira is located $20 \mathrm{~km}$ away from the municipal center of Caetité, with an annual average temperature ranging between 15 and $27{ }^{\circ} \mathrm{C}$ and an average annual rainfall of approximately $743 \mathrm{~mm}$ (INMET, 2018). The region is characterized by a dry season from May to October and a rainy season from November to April. C. heliotropiifolius plants were sampled from natural clusters composed of a few, sparsely distributed plants or from groups of more than 20 individuals spread across a 2 ha grassland currently under regeneration.

\section{Floral biology}

To estimate the number of inflorescences per individual and flowers per inflorescence, we first determined the mean number of inflorescences produced by mature individuals (height: $1.5 \mathrm{~m})(\mathrm{n}=$ 10) and then estimated the mean number of pistillate and staminate flowers borne on each inflorescence. Additionally, we monitored the development of staminate and pistillate flowers daily in five marked inflorescences of four individuals from the bud stage through senescence, and recorded the hour of anthesis and the period of pollen release (PASSOS, 1995; DAFNI; KEVAN; HUSBAND, 2005). Lengths of stylets and stigmas $(n=40)$ were also measured using a digital caliper. For olfaction testing, fresh flowers were collected at 08:00 h in a sealed glass container and the released odor was analyzed after $3 \mathrm{~h}$ (DAFNI; KEVAN; HUSBAND, 2005).

To estimate the quantity of nectar produced, 40 pre-anthesis bud-stage inflorescences from randomly selected, staminate and pistillate flowers were isolated for 48 and $24 \mathrm{~h}$, respectively, using organza bags after bud opening. Nectar from the 20 pistillate flowers (one flower per inflorescence) was withdrawn using a $10 \mu \mathrm{L}$ micro syringe, and nectar sugar concentration was estimated using a refractometer (scale: 0-90\%). However, owing to insufficient nectar production, nectar measurements in the 20 staminate flowers were made using Whatman filter paper No. 1, following the protocol described by Dafni, Kevan and Husband (2005).

Additionally, we determined the visitation patterns of bees including, collected resources, bee behavior, frequency per inflorescence per hour, and visiting time, all by direct, continuous visual observations between 05:00-18:00 h over 16 days, for a total of $192 \mathrm{~h}$ of observation. Plants with the largest number of pistillate flowers were selected for observation during the first eight days (96 h), while individuals with maximum abundance of staminate flowers were observed during the next eight days (96 h). We followed the protocol proposed by Dafni, 
Kevan and Husband (2005) to estimate the amount of pollen grains in the 40 pre-anthesis buds, which was used to determine pollen grain availability in flowers exposed to 5 and 10 visitations from $A$. mellifera individuals. The presence of starch and lipids in the pollen grains was estimated colorimetrically using Lugol and Sudan IV reagents, respectively.

\section{Flowering phenology}

We recorded the phenology of 30 marked individuals semi-quantitatively on a biweekly basis from September 2017 to August 2018. We assessed flowering intensity by assigning individual plants to one of the following five categories (FOURNIER, 1974): $0=$ absence; $1=1-25 \% ; 2=26-50 \% ; 3=$ $51-75 \%$; and $4=76-100 \%$. Moreover, the flowering index was evaluated following the methodology of Bencker and Morellato (2002), which involves qualitative estimation of the presence or absence of flowering individuals in the population.

Subsequently, the number of staminate and pistillate flowers was quantified at the population level using five inflorescences randomly selected in 20 individuals on a weekly basis throughout the flowering period. The pattern of sexual expression (PS) of the species was determined by dividing the number of pistillate flowers by the number of staminate flowers; where, $\mathrm{PS}=0$ indicated only staminate flowers, $\mathrm{PS}=\mathrm{E}$ indicated only pistillate flowers, and $\mathrm{PS}>0$ indicated overlap with presence of staminate and pistillate flowers (DOMÍNGUEZ; BULLOCK, 1989).

\section{Statistical analysis}

Spearman correlation index was used to assess the effects of the climatic variables (temperature and rainfall) on flowering, while flowering synchrony in the population was measured using the synchrony index $(Z)$; where, $Z=0$ indicated no synchrony, $Z>0.5$ indicated high synchrony, and $\mathrm{Z}=1$ indicated perfect synchrony (AUGSPURGER, 1983; PEDRONI; SANCHEZ; SANTOS, 2002).

\section{RESULTS AND DISCUSSION}

\section{Floral biology}

The monoecious shrub $C$. heliotropiifolius was found to bear $560 \pm 60$ inflorescences per plant (Figure 1a), with diclinous flowers borne on erect racemes (Figures 1b-c). There were $59 \pm 12$ and $160 \pm 26$ pistillate and staminate flowers per inflorescence, respectively; thus, approximately $73 \%$ of the flowers borne on an inflorescence were staminate, which is a characteristic feature of the species (REDDI; SUBBA-REDDI, 1985;
DOMÍNGUEZ; BULLOCK, 1989; PASSOS, 1995; PIRES; SOUSA; TERADA, 2004). Pistillate and staminate flowers lasted on the inflorescences for three and two days, respectively.

Flowers blossomed acropetally, with pistillate flowers always maturing earlier than staminate flowers. Thus, in a selected inflorescence, the female phenophase (i.e., anthesis of pistillate flowers), which lasted for six days, occurred in two consecutive 3 day periods (Figure 1b). Five days after the female phenophase, the male phenophase (i.e., anthesis of the staminate flowers) began in the inflorescences, with 10 flowers blossoming every day for the next 16 days (Figure 1c).

Pistillate flowers were pedicellate, with five light-green sepals and three styles, each measuring 1 $\mathrm{mm}$, with $3.3 \pm 0.2 \mathrm{~mm}$-long bifid stigmas $(\mathrm{n}=40)$ (Figure 1d). The ovaries were brown and superior with three uniovulate locules and axial placentation, and orange nectar glands were located between the sepals and the ovary (Figure 1d). The pistillate flowers matured slowly, and the maturation process extended from the early hours of the day up to 12:00 $\mathrm{h}$, during which complete flower anthesis occurred, which was indicated by the complete horizontal extension of the styles to expose the bifid stigmas with their ends facing upwards. The mean volume of nectar produced per pistillate flower was $2.8 \pm 0.8 \mu \mathrm{L}$, with a sugar concentration of $13.4 \pm 4.1 \%$; the flower odor was characterized as sweet.

Pedicellate staminate flowers were also pentamerous, with green sepals and inconspicuous white petals, and had $22 \pm 2$ stamens per flower (Figure 1e). Filaments were showy, with basifixed anthers and longitudinal dehiscence, and the nectar glands were located at the attachment points of the filaments (Figure 1e). Complete anthesis in staminate flowers occurred at 08:00 h, exposing the pollen grains for release at 09:00 $\mathrm{h}$. The amount of nectar recorded in staminate flowers was $0.3 \pm 0.06$ $\mu \mathrm{L}$, and the sugar concentration was too low to be measured. However, similar to the pistillate flowers, the odor released by the staminate flowers was characterized as sweet.

Although both pistillate and staminate $C$. heliotropiifolius flowers produced nectar, $A$. mellifera individuals visited staminate flowers more frequently for pollen grains (Figure 1f).

Plants with dense terminal inflorescences, such as $C$. heliotropiifolius, are showy and thus attract a great diversity of visitors (GORAIN; CHARAN; AHMED, 2012). Moreover, the reproductive morphological characteristics of $C$. heliotropiifolius reported in the present study, including inconspicuous radial flowers with sweet odor, are consistent with reports on species with greater potential for apiculture in the northeast region of Brazil, such as C. blanchetianus Baill, $C$. grewioides Baill. and $C$. sonderianus Müll. Arg. (SANTOS et al., 2018). 

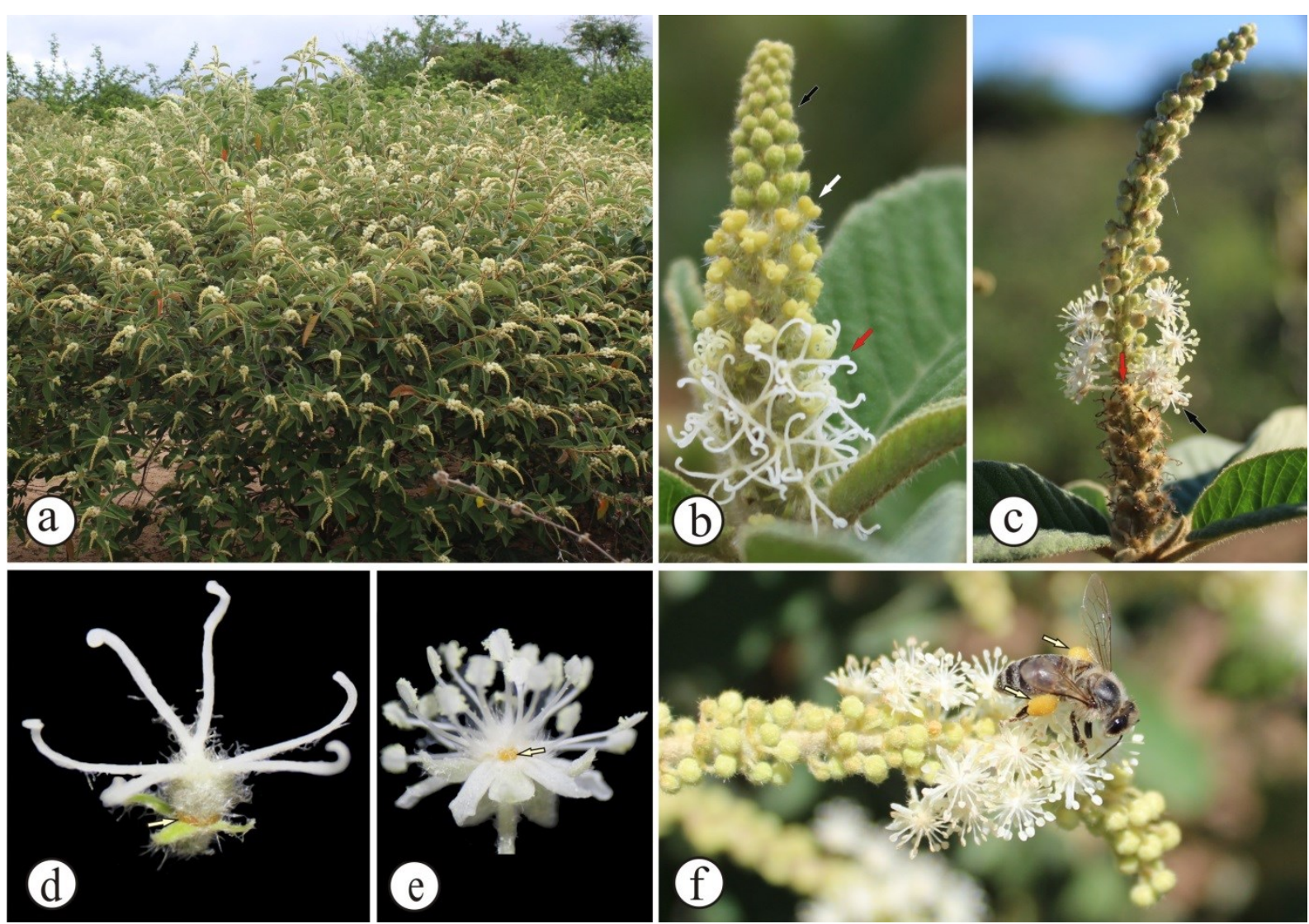

Figure 1. a. Individuals of Croton heliotropiifolius Kunth (Euphorbiaceae) showing inflorescences exposed above the foliage; b. An inflorescence during anthesis in pistillate flowers (red arrows) showing buds of pistillate (white arrows) and staminate flowers (black arrows); c. An inflorescence during anthesis in staminate flowers showing senescence of pistillate flowers (red arrows) and the beginning of anthesis in staminate flowers (black arrows); d. Nectar glands in a pistillate flower (arrow); e. Nectar glands in a staminate flower (arrow); f. Workers of Apis mellifera L., 1978, foraging on staminate flowers at Fazenda Ingazeira, Caetité, Bahia, Brazil.

The visiting frequency by $A$. mellifera individuals on pistillate flowers was $2 \%$, with the peak visitation period between 06:00 $\mathrm{h}$ and 09:00 $\mathrm{h}$ (Figure 2a), while $98 \%$ of the visits were recorded on staminate flowers, with the peak visitation period from 08:00 h to 11:00 h (Figure 2b). Moreover, $A$. mellifera workers visited staminate flowers until 12:00 $\mathrm{h}$ daily, indicating that the primary resource of interest was the pollen grains, as the highest number of visits were recorded between 06:00 and 12:00 h, which included the period during which anthesis occurred (08:00-09:00 h). Reddi and Subba-Reddi (1985) reported similar observations in $C$. bonplandianus Baill, wherein Apis workers concentrated exclusively on staminate flowers for foraging pollen grains.

The pollen grains of $C$. priscus Croizat and $C$. floribundus Spreng are the main floral resource foraged by workers of $A$. mellifera (PASSOS, 1995). However, these bees forage other species for nectar (PIRES; SOUSA; TERADA, 2004), for example, in C. urucurana Baill, bees forage for pollen grains in the morning (09:00-11:00 h) and for nectar produced in pistillate flowers in the afternoon (15:00-17:00 h). Thus, the foraging behavior of bees on Croton species warrants further investigation. Moreover, in this study, $C$. heliotropiifolius was an important source of pollen grains for the worker bees of $A$. mellifera, while other species might exhibit different behaviors, foraging for nectar or both nectar and pollen, as reported in C. urucurana (PIRES; SOUSA; TERADA, 2004).

When mixed with regurgitated nectar and glandular secretions, pollen grains containing starch, such as those of $C$. heliotropiifolius, comprise a highly nutritious diet for bees (GHOSH; JUNG, 2017). Additionally, lipids, which increase the attractiveness of pollen grains, are essential for bees to synthesize royal jelly and accumulate energy reserves (DOBSON, 1988). Hence, large amounts of pollen grains are necessary for the development of healthy bee colonies (HUANG, 2012).

The data regarding to pollen grain available in the pre-anthesis buds, as well as on flowers exposed to five and 10 visitation of Apis mellifera specimens are be shown at Table 1 . 


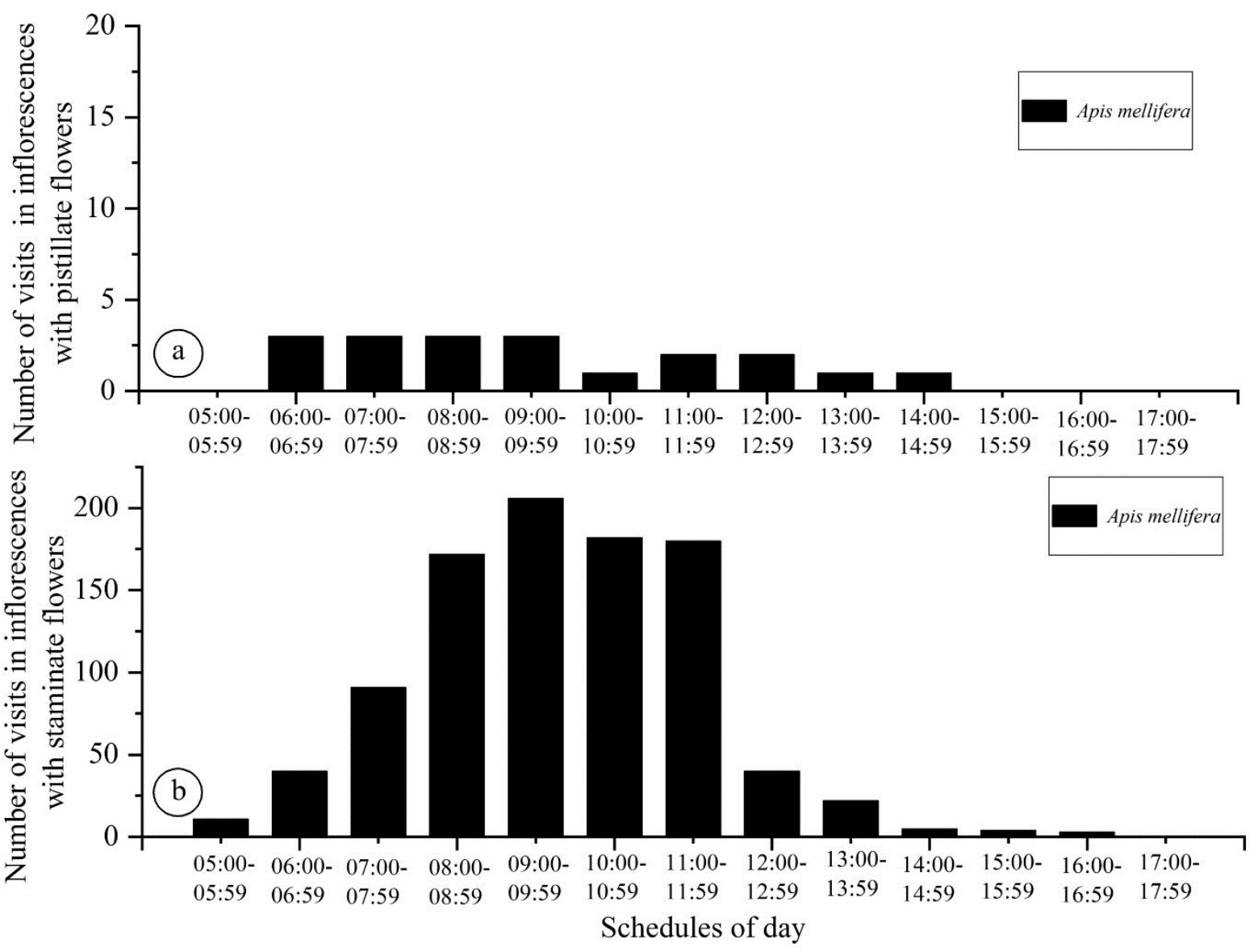

Figure 2. Daily visitation pattern of Apis mellifera L. individuals recorded during an observation period of 192 $\mathrm{h}$, between 05:00 $\mathrm{h}$ and 18:00 $\mathrm{h}$ in the inflorescences of Croton heliotropiifolius Kunth (Euphorbiaceae) at Fazenda Ingazeira, Caetité, Bahia, Brazil. a. Daily pattern of visits to pistillate flowers; b. Daily pattern of visits to staminate flowers.

Table 1. Availability of pollen grains in pre-anthesis buds and on flowers of Croton heliotropiifolius Kunth (Euphorbiaceae) exposed to 5 and 10 visitations of Apis mellifera L. workers at Fazenda Ingazeira, Caetité, Bahia, Brazil.

\begin{tabular}{cc}
\hline Analyzed parameters $(\mathrm{n}=40)$ & Quantity of available pollen grains \\
\hline Buds at pre-anthesis & $6000 \pm 1250$ \\
Flowers after 5 visits & $2500 \pm 1250$ \\
Flowers after 10 visits & $1950 \pm 1590$ \\
\hline
\end{tabular}

Based on the quantitative analysis of pollen grains available per flower (Table 1) and the number of flowers produced per individual of $C$. heliotropiifolius, the number of pollen grains produced by an individual with a canopy at chest height was estimated to be $5.376 \times 10^{8}$. As each individual bee was capable of removing c.a. 405 pollen grains per visit (Table 1), we estimated that each individual of $C$. heliotropiifolius had the capacity to support approximately 33 visitation cycles from a large colony of $A$. mellifera workers, which includes approximately $4 \times 10^{4}$ worker bees (ROUBIK, 1980). This indicates the potential of this Croton species to produce and provide pollen grains to the bees of $A$. mellifera.

Although the northeastern region of Brazil does not have commercial producers of bee pollen, the national and international demand for apicultural pollen for human consumption is growing (SANCHEZ et al., 2012). For example, in the state of Bahia, apicultural pollen production undertaken along the southern and extreme southern coast caters only the local demand (MEIRA et al., 2017), underlining the importance of the contribution of apiculture to the developing economy of this state. Therefore, further studies are required to investigate the potential of apicultural pollen-producing plants, such as $C$. heliotropiifolius, to meet the floral 
resources demand for human consumption.

\section{Flowering Phenology}

Flowering in $C$. heliotropiifolius occurred during the rainy season from the end of November to the beginning of April (Figure 3), and was significantly correlated with rainfall $(\mathrm{r}=0.66$, $\mathrm{p}=0.0043, \mathrm{n}=30)$ and temperature $(\mathrm{r}=0.62, \mathrm{p}=0.001$, $\mathrm{n}=30)$. However, the peak flowering phenophase ranged from December to January, during which, the indices were $>50 \%$ (Figure $3 \mathrm{~b}$ ). Moreover, the high activity indices recorded in the months of December (94\%), January (100\%), and the second-half of February (94\%), and a synchrony index of 0.77 illustrated the annual flowering pattern of $C$. heliotropiifolius, wherein all individuals of the population flowered at the same time during the reproductive cycle (Figure $3 b$ ).
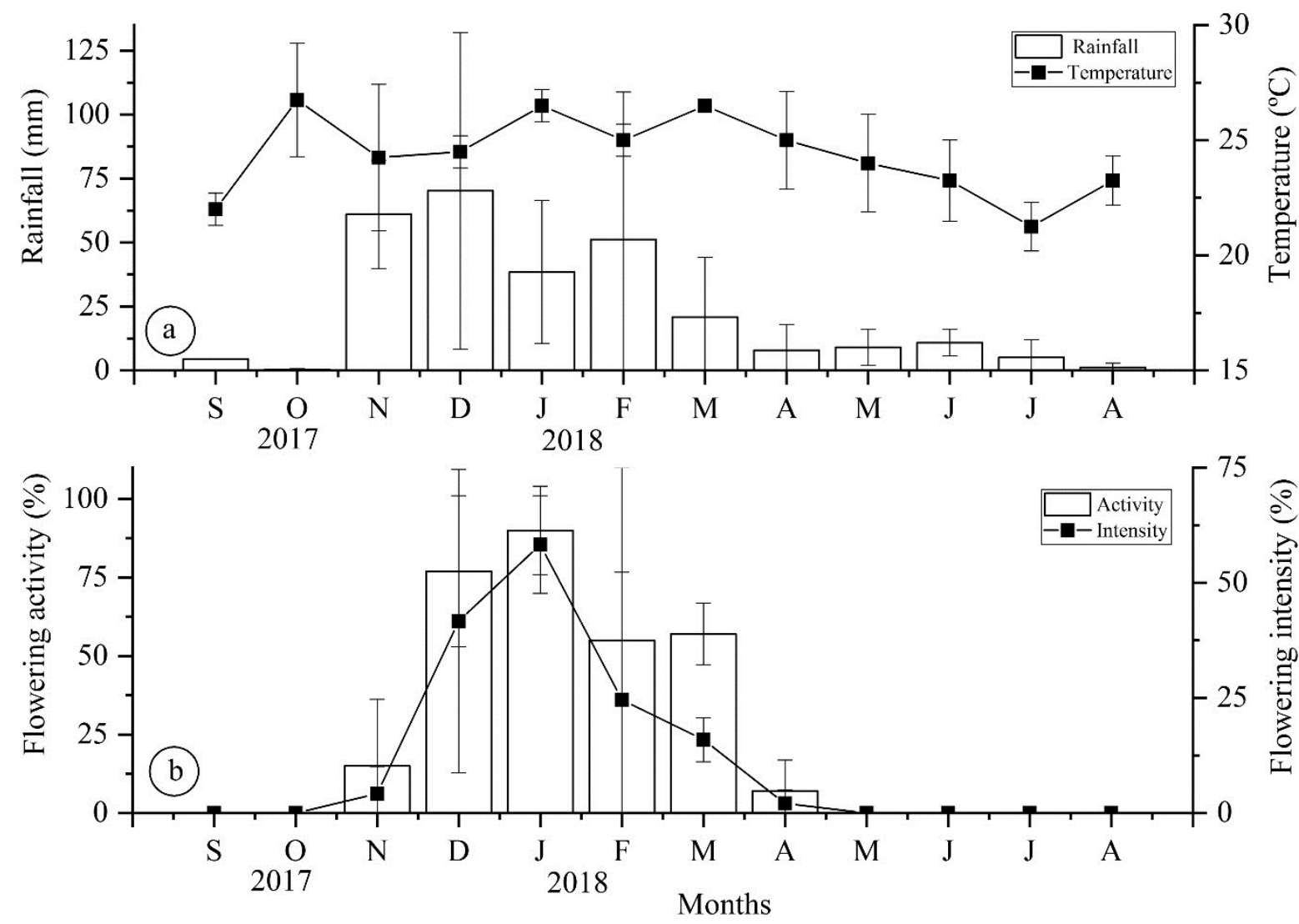

Figure 3. a. Mean monthly rainfall and temperature data (with standard deviations) of Caetité, Bahia, Brazil, from September 2017 to August 2018, based on the data collected at station 83339 of the Instituto Nacional de Meteorologia (INMET); b. Mean monthly flowering activity and flowering intensity (with standard deviations), in Croton heliotropiifolius Kunth (Euphorbiaceae) at Fazenda Ingazeira, Caetité, Bahia, Brazil.

The annual flowering pattern in $C$. heliotropiifolius (NEWSTROM; FRANKIE; BAKER, 1994), along with the cornucopia flowering strategy (GENTRY, 1974), is a phenological characteristic that ensures greater number of flowers and floral resources in their environments for several days (FERNANDES; VENTURIERI; JARDIM, 2012), thereby supporting foraging by several nonspecialized visitor guilds.

The weekly quantitative phenological survey of available flowers (open flowers) on the five inflorescences of randomly selected individuals revealed three peaks of staminate flower production, namely, December (81.7\%), January (54.5\%), and February (95.7\%). However, the peak in pistillate flower production was observed only in January $(45.5 \%)$, indicating that staminate flowers were more abundant (Figure 4a). Moreover, the PS in the selected individuals (Figure $4 \mathrm{~b}$ ) revealed that most flowers exhibited exclusively male functions $(\mathrm{PS}=0)$ in December, January, and February, while only a few individuals exhibited exclusively female functions $(\mathrm{PS}=\mathrm{E})$, and a considerable number of individuals exhibited overlaps between the two ( $\mathrm{PS}>0$ ).

Therefore, the high frequency of visits from A. mellifera workers on staminate flowers can be attributed to the dominance of these flowers in $C$. heliotropiifolius populations during the flowering period. 

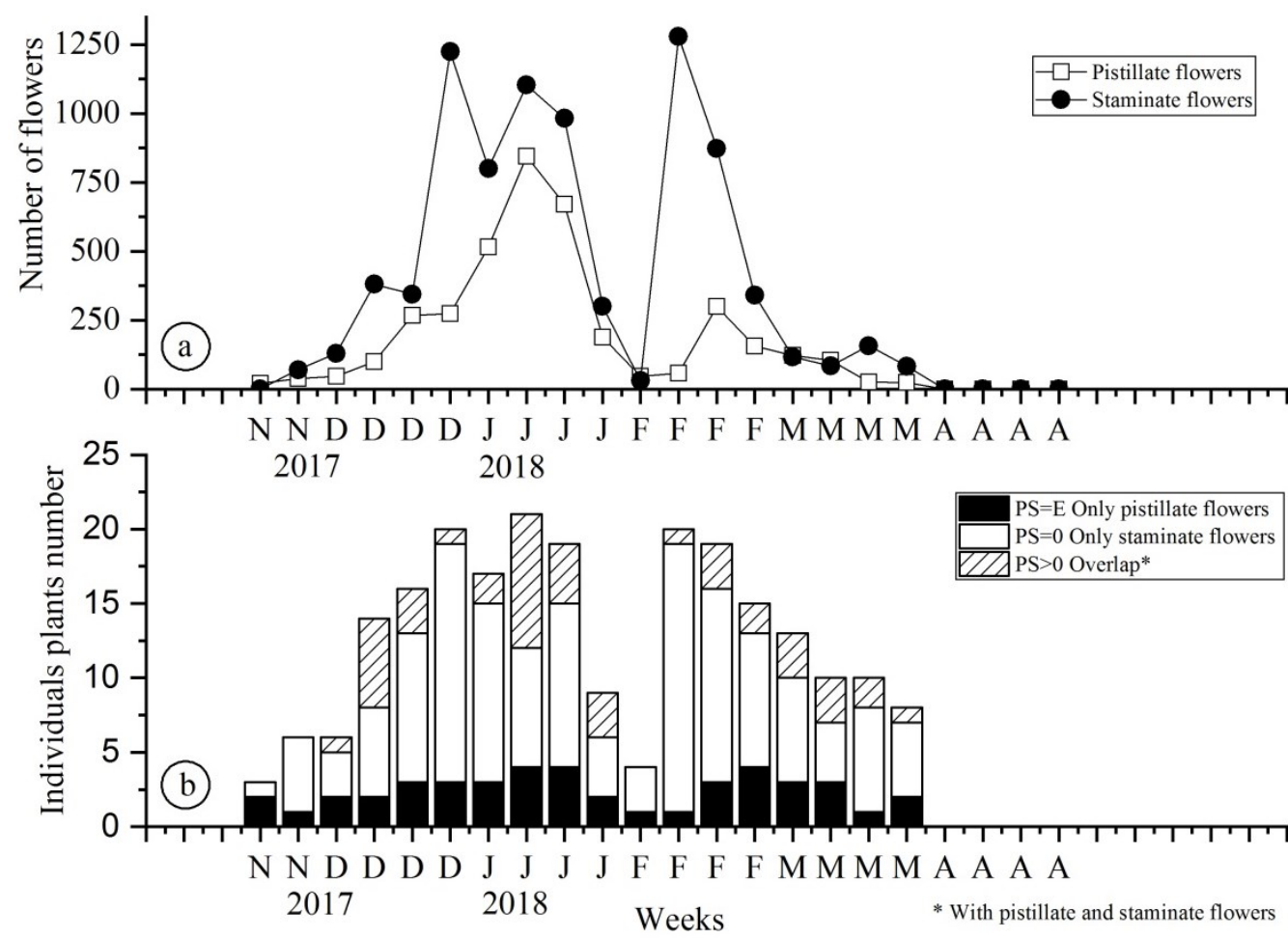

Figure 4. a. Weekly quantitative phenological survey data of available (open) flowers on five inflorescences per individual $(\mathrm{n}=20)$ of Croton heliotropiifolius Kunth (Euphorbiaceae) during the flowering period (22 November 2017-28 March $2018)$; b. Weekly data of patterns of sexual expression in C. heliotropiifolius $(\mathrm{n}=20)$ during the flowering period at Fazenda Ingazeira, Caetité, Bahia, Brazil.

\section{CONCLUSION}

The beekeeping potential of $C$. heliotropiifolius is clearly highlighted by the high visitation rates of bees to its flowers, its intense and synchronous flowering, and its capacity to produce abundant pollen grains, which serve as an important nutrition source for A. mellifera. These characteristics reveal the importance of the utilization and management of $C$. heliotropiifolius in beekeeping activities.

\section{ACKNOWLEDGEMENTS}

We gratefully acknowledge the staff members of the Palynology Study Laboratory, Departament of Exact and Earth Sciences and Palynology Study Laboratory (LAEP), Departament of Human Sciences of the Universidade do Estado da Bahia (UNEB) for their technical support. We also thank DS Carneiro-Torres for confirming the species under study.

This study was supported by a research grant from Coordenação de Aperfeiçoamento de Pessoal de Nível Superior - Brazil (CAPES) - Financing Code 001 .

\section{REFERENCES}

AUGSPURGER, C. K. Phenology, flowering, synchrony, and fruit set of six neotropical shrubs. Biotropica, 15: 257-267, 1983.

ABOU-SHAARA, H. F. Potential honey bee plants of Egypt. Cercetări Agronomice în Moldova, 48: 99-108, 2015.

BENCKER, C. S. C.; MORELlATO, L. P. C. Comparação de dois métodos de avaliação da fenologia de plantas, sua interpretação e representação. Revista Brasileira de Botânica, 25: 269-275, 2002.

BLUTHGEN, N. Interações plantas-animais e a importância funcional da biodiversidade. In: DELCLARO, K.; TOREZAN-SILINGARDI, H. M. (Eds.). Ecologia das interações plantas-animais: uma abordagem ecológica. Rio de Janeiro, RJ: Technical Books, 2012. v. 1, cap. 13, p. 261-272.

CARUZO, M. B. R. et al. Croton in Flora do Brasil 2020. Jardim Botânico do Rio de Janeiro. 2020. Disponível em: <http://floradobrasil.jbrj.gov.br/ reflora/floradobrasil/FB17497>. Acesso em: 29 abr. 2021. 
DAFNI, A.; KEVAN, P. G.; HUSBAND, B. C. Practical pollination biology. 1. ed. Cambridge, UK: Enviroquest, 2005. 590 p.

DOBSON, H. E. M. Survey of pollen and pollenkitt lipids: Chemical cues to flower visitors?. American Journal of Botany, 75: 170-182, 1988.

DOMÍNGUEZ, C.; BULLOCK, S. H. La reproduccion de Croton suberosus (Euphorbiaceae) en luz y sombra. Revista de Biologia Tropical, 37 : 1-10, 1989.

FERNANDES, M. M.; VENTURIERI, G. C.; JARDIM, M. A. G. Biologia, visitantes florais e potencial melífero de Tapirira guianensis (Anacardiaceae) na Amazônia Oriental. Revista de Ciências Agrárias Amazonian Journal of Agricultural and environmental Sciences, 55: 167175, 2012.

FOURNIER, L. A. Un método cuantitativo para la medición de la características fenológicas en árboles. Turrialba, 24: 422- 423, 1974.

GENTRY, A. H. Flowering phenology and diversity in tropical Bignoniaceae. Biotropica, 6: 64-68, 1974.

GORAIN, M.; CHARAN, S. K.; AHMED, S. I. Record of honey bees in pollination of Acacia nilotica Willd ex del. (leguminosae, subfamily mimosoideae) in Rajasthan. Journal of Entomological Research, 36: 215-218, 2012.

GOREVITCH, J.; SCHEINER, S. M.; FOX, G. A. Ecologia vegetal. 2. ed. Porto Alegre, RS: Artmed, 2009. 592 p.

\section{GBIF SECRETARIAT. Euphorbiaceae in GBIF} Secretariat. GBIF Backbone Taxonomy. Disponível em: https://doi.org/10.15468/39omei. Acesso em: 21 de ago. 2019.

GHOSH, S.; JUNG, C. Nutritional value of beecollected pollens of hardy kiwi, Actinidia arguta (Actinidiaceae) and oak, Quercus sp. (Fagaceae). Journal of Asia-Pacific Entomology, 20: 245-251, 2017.

HUANG, Z. Pollen nutrition affects honey bee stress resistance. Terrestrial Arthropod Reviews, 5: 175189, 2012.

HURBATH, F.; CARNEIRO-TORRES, D. S.; ROQUE, N. Euphorbiaceae na Serra Geral de Licínio de Almeida, Bahia, Brasil. Rodriguésia, 67: 489-531, 2016.

INMET - Instituto Nacional de Meteorologia. Normais climatológicas do Município de Caetité-
BA, 1993-2017. Disponível em: https:// portal.inmet.gov.br/dadoshistoricos. Acesso em 31 abr. 2018

MEIRA, J. N. et al. Agronegócios: produção de pólen. 1. ed. Salvador, BA: SEBRAE, 2017. 39 p.

MORIMITSU, P. W.; VERGENE, M. C. S.; TOMAZ, A. F. Gestão socioambiental em pequenas propriedades rurais no bioma Caatinga. Revista Ouricuri, 4: 155-179, 2014.

NEWSTROM, L. E.; FRANKIE, G. W.; BAKER, H. G. A new classification for plant phenology based on flowering patterns in Lowland Tropical rain forest trees at La Selva, Costa Rica. Biotropica, 26:141159, 1994.

PASSOS, L. C. Fenologia, polinização e reprodução de duas espécies de Croton (Euphorbiaceae) em mata semidecídua. 1995. 84 f. Dissertação (Mestrado em Ciências Biológicas: Área de concentração em Biologia Vegetal) Universidade Estadual de Campinas, São Paulo, 1995.

PEDRONI, F.; SANCHEZ, M.; SANTOS, F. A. M. Fenologia da Copaiba (Copaifera langsdorffii Desf.Leguminosae, Caesalpinioideae) em uma floresta semidecídua no sudeste do Brasil. Revista Brasileira de Botânica, 25: 183-194, 2002.

PIRES, M. M. Y.; SOUSA, L. A.; TERADA, Y. Biologia floral de Croton urucurana Baill. (Euphorbiaceae) ocorrente em vegetação ripária da Ilha Porto Rico, estado do Paraná, Brasil. Acta Scientiarum, Biological Sciences, 26: 209-215, 2004

REDDI, E. U.; SUBBA-REDDI, C. Wind and insect pollination in a monoecious and a dioecious species of Euphorbiaceae. Indian National Science Academy, 51: 468-482, 1985.

ROUBIK, D. W. Foraging behavior of competing Africanized honeybees and Stingless bees. Ecology, 61: 836-845, 1980

SANCHEZ, X. et al. Organic Bee Pollen: Botanical Origin, Nutritional Value, Bioactive Compounds, Antioxidant Activity and Microbiological Quality. Molecules, 17: 8359-8377, 2012.

SANTOS, F. A. R. et al. Espécies melíferas. In: CORADIN, L.; CAMILLO, J.; PAREYN, F. G. C. (Eds.). Espécies nativas da flora brasileira de valor econômico atual ou potencial. Brasília, DF: Ministério do Meio Ambiente, 2018. v. 51, cap. 5, p. 971-1010. 
SANTOS, F. A. R. et al. Plantas do semi-árido importantes para as abelhas. In: GIULIETTI, A. M.; QUEIROZ, L. P.; SANTOS, F. A. R. (Eds.). Apium plantae. Recife, PE: IMSEAR, 2006. v. 3, cap. 3, p. 61-96.

SILVA, J. S. et al. Sinopse das espécies de Croton L. Euphorbiaceae) no estado de Pernambuco, Brasil. Acta Botânica Brasilica, 24: 441-453, 2010.

SILVA, O. L. M. et al. Euphorbiaceae in Flora do Brasil 2020. Jardim Botânico do Rio de Janeiro. 2020. Disponível em: <http:// floradobrasil.jbrj.gov.br/reflora/floradobrasil/ FB113>. Acesso em: 29 de abr. 2021. 